\title{
Spatial politics and gendered strategies: women traders and institutions in Oke Arin market, Lagos
}

\author{
Nkechi Eke Nwankwo
}

\begin{abstract}
Introduction
The engagement of women as traders in Nigerian and West African market places has been richly reflected in the published literature (Sudarkasa 1973; Clark 1994; Byfield 2002; Lawal 2004; Prag 2013). In this article, market is used as a shorthand for market place, a physical location for the exchange of goods and services. The market place refers to where there are 'aggregates of sellers as well as aggregates of buyers' (Handwerker 1974: 232). There are about 400 markets in Lagos (Ikioda 2012: 36), and the majority of sellers or traders are women because trading is the main occupation for women in the city (Peil 1991). But whether, how and to what extent women's engagement in markets translates into power and control of resources vary by context.

Some literature (Little 1972; Barnes 1986; Lawal 2004; Ikioda 2012) suggests that women traders in Lagos are cohesive, wield enormous power and control the markets. Those suggestions have largely been based on the proportion of women traders in the markets and the top positions women hold in market associations (Little 1972; Barnes 1986). However, this study suggests that the appearance of women being in control may sometimes be deceptive; market power dynamics may relegate the majority of Lagos women traders to a subordinate position and put them in constant contestation with male-dominated market power structures.

I use empirical data from Oke Arin market to answer the question 'How do women traders negotiate spatial relationships to facilitate their trading ventures?' In doing so, I examine the gendered meanings of the spaces in Oke Arin market through data on market governance, ethnic politics, ownership and access to shops and stalls, sanitation and the enforcement of rules. The data for this analysis were collected over a one-year period (May 2015 to May 2016) in Lagos, Nigeria. The study involved a sample of eighty Yoruba women traders, government and market officials, and used a mix of methods including a survey, in-depth interviews, unstructured conversations, observation and secondary data analysis.
\end{abstract}

\section{Background}

Market places in Yorubaland (of which Lagos is a part) serve as spaces for economic and social exchanges (Sudarkasa 1973; Lawal 2004; Ikioda 2012).

\footnotetext{
Nkechi Eke Nwankwo earned her PhD as a University of East Anglia Africa scholar at the School of International Development, University of East Anglia. Her research interests include women's economic and political leadership. Email: nkechien@gmail.com
}

(C) International African Institute 2019 
Outlining how markets were traditionally established in Yorubaland, Sudarkasa (1973: 57) noted that 'it was the chief ruler who established or authorized the establishment of the markets in his town'. Once created, the markets were largely handed over to the management of women market leaders (Mba 1987: 224). However, in 1949, the British colonial government took over the power to create and manage markets. Based on the Market Ordinance of 1949, all markets in the Western Region (to which Lagos belonged) were thenceforth legally under the control of the city council (Sudarkasa 1973: 57). Although the city council employed male market masters to administer the markets, organization of the traders in most markets remained in the hands of women, partly because the market masters were too few to cover all markets (Mba 1987: 248). However, the women market leaders reported to market masters. So, while women comprised the greater number of traders, men became the decision makers and 'owners' of the market space.

Since Nigeria's independence in 1960, governments have maintained their hold on the administration of markets. The three-tier government structure in Nigeria (federal, state and local council) gives the mandate for administering markets to local councils. But in Lagos, the state continues to be involved and local councils continue to employ (male) market masters to administer markets. As Ikioda (2012: 37) and Fourchard and Olukoju (2007: 110) point out, the state and councils tend to rely on market associations to regulate traders and collect revenues. In 1980, the Lagos state government established the Market Development Board to build shopping centres and increase state revenue (Lagos State Ministry of Information 1988).

The government's interference in market relationships as well as broader economic factors have had an impact on power dynamics in markets in Lagos. For instance, with the structural adjustment of the Nigerian economy in 1986, many more people - women and men - joined the informal sector, which mostly meant hawking and trading in Lagos (Rao et al. 2009a; 2009b). Most of the men who began trading in Lagos were Igbos, increasing the competition and adding a complex layer of gender and ethnicity. Following the marked increase in Igbo (male) traders in Lagos, particularly in the last two decades, they have also formed traders' associations along ethnic lines in the various markets.

The current dynamics in Lagos markets demand a re-examination of their discursive construction as a space where women are in charge (Sudarkasa 1973; Mba 1987: 247). Sudarkasa's (1973: 155) stance is that, 'in Yoruba society, the world of the market is primarily a woman's world', and she claims that gender-power relations privilege women in the market context. But the current reality, as I will show in this article, is that the market is in constant contestation, being shaped and controlled through gendered power struggles. The leadership of many market associations in Nigeria has largely been co-opted to serve the interests of men in government and not their members, the traders (Meagher 2011; Ikioda 2014).

In Lagos, market association leaders draw power and legitimacy from their connections with government rather than from the traders; this is similar to the findings from other West African countries, such as Benin (Prag 2013) and Ghana (Clark 1994). This turns market associations into quasi-governments and reflects Meagher's analysis that there may be a 'blurring of the distinction between the formal and informal institutions, and the ways in which informal institutions shape power relations' in some African contexts (Meagher 2007: 412). 
With government co-opting market associations, the majority of women traders find that the only weapons they have are resistance and other so-called 'weapons of the weak' (Scott 1985).

Indeed, Yoruba women traders' resistance of government (and men's) attempt to control the markets dates back to the 1890s. Byfield (2002) highlighted the collusion of government authorities (colonial and local) in polarizing (Yoruba) Abeokuta women traders' associations during the early colonial period (18901940) and how the women fought back. Similarly, Mba (1982) recorded the mobilization of numerous Yoruba market women against the colonial government's price fixing and planned taxation from 1920 to 1940. In Lagos, recorded conflicts between various governments and women traders since the 1930s have been centred on space and taxation (Lawal 2004; George 2011). These two points of conflict remain, but the government's increasing involvement in the installation of market association leaders (iyaloja) since the 1990s further complicates the situation.

Massey (1994: 179) argues that space is gendered and reproduces the power relations in a specific context. For this analysis, it is important to understand the context as the broader Lagos society, not just the market space. In other words, the gendered power relations in wider society are reproduced in the market, despite the illusion of women's power and control. So, the way in which men and women relate in a particular setting (in this case, Lagos) imbues that space with a symbolic meaning and genders it. Massey (ibid.) points out that those meanings are maintained by various means, including violence, but they are not without contestation.

Massey's analysis of the intersection of space and gender is exemplified on several levels by the relationships in Oke Arin market, Lagos. The multiple, complex relationships between individuals and groups of actors - including traders, buyers, landlords, market leaders and government officials - both construct gendered spaces and replay the gender constructions in the wider context. These gendered constructions and their symbolic meanings and implications are also contested sites realized through the spatial politics of competing claims, strategies of navigation, and the enforcement of market rules. Among the most obvious contests that reproduce gender relations of power are claims around the governance, ownership and usage of space.

\section{Context}

Lagos is Nigeria's ethnically diverse economic capital, with Yorubas comprising about 60 per cent of the population (Barnes 1975).The next largest ethnic group in Lagos are Igbos (Adebanwi 2004: 34), but current official figures are unavailable. Men predominantly occupy decision-making positions in private and public spheres. For instance, the forty-member Lagos State House of Assembly has just four female members. Yoruba women are expected to be economically active and engaged in family provisioning (Mann 1983). Trading is the main economic activity and markets are constructed as 'women's space' (Sudarkasa 1973). Based on the Yoruba cultural gendered division of labour, women generally trade while men farm (Eades 1980). 
The Oke Arin market area is located in the central business district of Lagos Island and administratively falls under the Lagos Island local government council. An official of the local council noted that Oke Arin is designated a 'professional market' because it developed organically (as opposed to the 'conventional' markets, which are those built legitimately by the government). Formerly a residential area, Oke Arin began turning into a market in the 1930s as residents brought out wares to sell on the street and street traders joined them; to date, the boundaries of the market have remained somewhat fluid. In the 1980s, the government designated Oke Arin a market and worked with the traditional authorities to appoint a woman market leader (iyaloja) to run it. At the time of my field research, the market area included roughly twenty streets with the following boundaries: Idita Street in the north; Apogbon Street in the west; John Street in the east; and Williams Street in the south. It covers an area of about 158,700 square metres with a perimeter of 1.6 kilometres (see Figures 1, 2 and 3).

Although Oke Arin has evolved into a market, most buildings still host residents on their top floors. Many of the buildings in Oke Arin are multiple-storey houses, mostly owned by the traditional Yoruba families who first settled on Lagos Island. The land and houses in the area are securely guarded by family heads (usually male) and passed on to generations of sons. Even as commerce is overtaking the former residential area, the families are careful not to hand over ownership through outright property sale. So, they settle for long leases or part rental. Typically, the house owners live on the topmost floors and rent the ground and first floors for shops and storage respectively.

A few of the property owners in the Oke Arin market area have been able to work with private developers to turn their buildings into shopping plazas. Like the partly residential buildings, the plazas are largely owned and managed by men. Even the open spaces are usually rented out by the market leaders (who, as I will discuss later, are also mostly men). Given the above scenario, the majority of landlords in the private and unregulated rental market are men, with women traders forming the bulk of their clientele.

\section{Market governance, gender and ethnicity}

Ethnicity is significant in the market's internal organization as it produces a different set of social relations and contestations for space. As Silvey (2006: 72) notes in relation to gender and migration, 'spatial controls are intertwined with social hierarchies and power relations'. Although contested, ethnicity is a marker of the social hierarchies and power relations in Oke Arin. Besides the Yoruba, the next major ethnic group in the market is the Igbo. The Igbo traders are mostly men who deal largely in imported food, wines and other beverages. According to the executives of the Igbo traders' association, Igbos make up approximately 30 to 40 per cent of traders in most sections of Oke Arin market. There is also a handful of Hausa male traders who are mainly fruit hawkers and head porters.

Markets form part of the remit of local government. However, Lagos State government has maintained a stronghold over the markets, given that they typically 


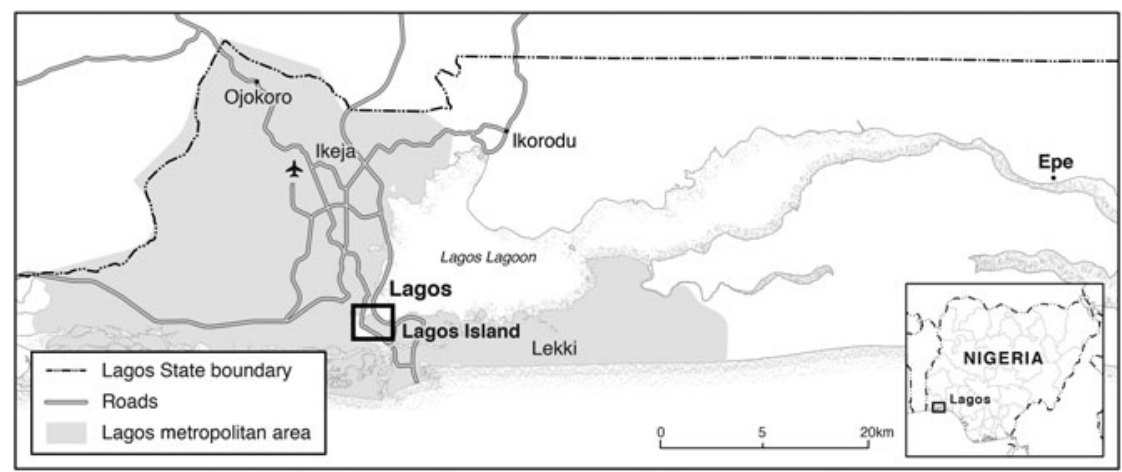

FIGURE 1 Map of Lagos State showing the location of Lagos Island.

generate high levels of revenue. The state uses numerous activities to hold on to the governance of markets. Two examples illustrate this: one is the establishment of the Market Development Board in 1980 to build 'sophisticated shopping centers that local governments could not handle single-handedly' (Lagos State Ministry of Information 1988: 148). The state noted in its handbook that 'although the establishment of the Market Development Board was seen as an aberration and encroachment of the local government function, the performance of the board has vindicated its establishment' (ibid.: 148). In effect, the state claimed that the allegedly positive results of its action justified the illegality. Another, more subtle, encroachment is made by the State Ministry of Local Governments by trying to get traders to form associations along their product lines. The associations are encouraged to register with the state at the rate of 10,000 Nigeria naira (NGN) - about US\$28 - per association per year. The state's sole interest is in increasing its revenue base, as the associations gain no benefits from being registered.

According to market authorities, in addition to whatever product line association a trader chooses to belong to, all traders must also belong to the traditional market association run by an 'iyaloja' - a term meaning 'mother of the market'. Writing on the role of the 'mother of the market' in her study of Mushin, Lagos, Barnes (1986: 162) notes that the iyaloja 'wielded a range of powers' and that 'without her support and the market association's approval it was impossible to rent a stall or to trade casually in the market'. In Oke Arin market, the iyalojas nominally hold such powers but they are constantly challenged by a number of factors and forces, one of them being the Igbo Oke Arin Traders Association. The powers of the iyaloja and her market association are better understood in the light of their close ties with both Lagos's traditional rulers and the government. Mba (1987: 248) argued that 'the market women were strong supporters of the traditional chiefs' and that their political support for the chiefs was shown by their participation in the campaign against water rates in 1908. She noted that 'the market women closed markets when meetings were held to protest the water rate and they raised the money to finance the campaign between 1908-1916'. Thereafter, the iyalojas and the market association openly supported any political party (and government) with which the traditional 


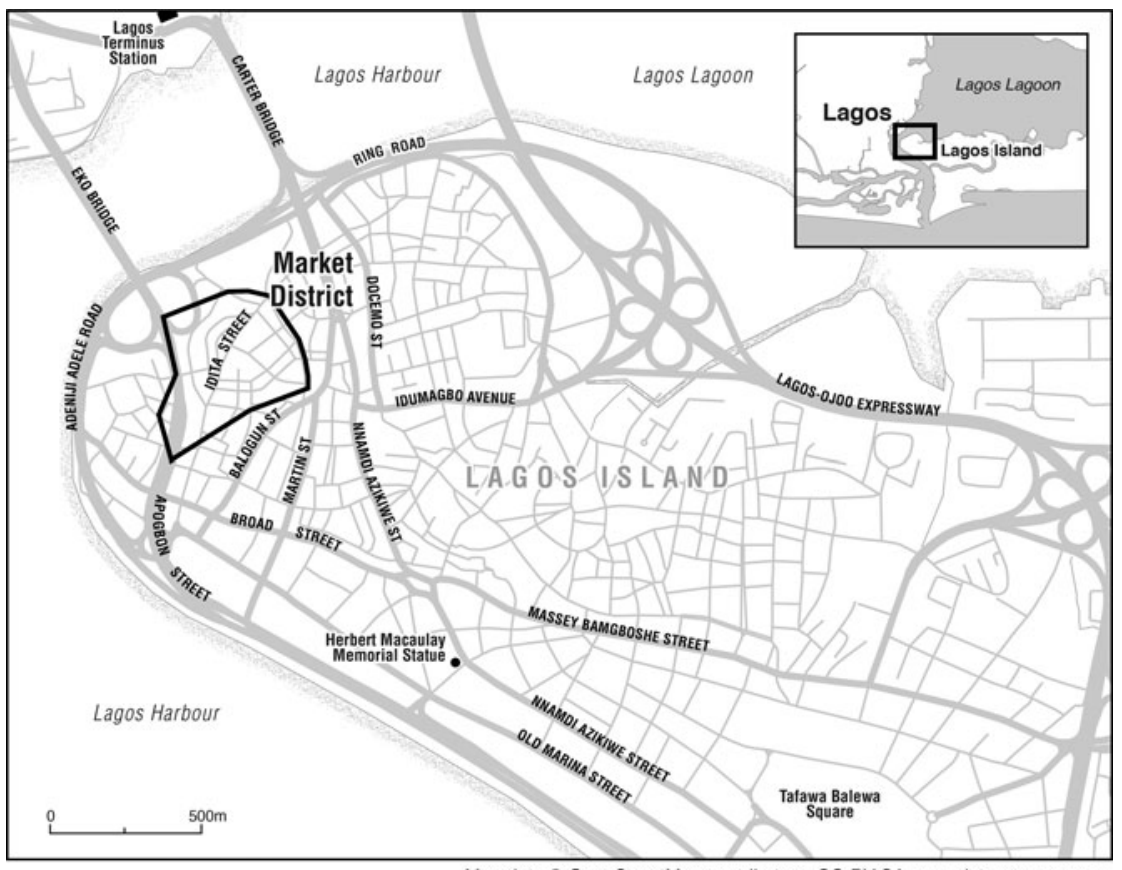

Map data (c) OpenStreetMap contributors, CC-BY-SA, opendatacommons.org

FIGURE 2 Map of Lagos Island showing the area in which Oke Arin market is located.

chiefs were aligned. Later, in the 1990s, the iyalojas were reorganized and recreated seemingly to mirror the tiers of government: iyaloja general of Nigeria (federal); iyaloja of Lagos (state); iyaloja of Lagos Island (local); and iyalojas of various markets and subsections of the markets (jurisdictions).

Indeed, it was widely acknowledged by various respondents that the position of iyaloja is now in many senses a political appointment by the traditional (and state) political machinery in Lagos. This goes against what Barnes (1986: 162) found in the Mushin context: that the 'mother of the market' was chosen by the traders. The current system of selecting the iyaloja and her officials does not involve the traders; the main iyaloja at Oke Arin told me that she was appointed due to her activism. She said: 'Before I became the iyaloja, I was an activist. In fact, I am a politician and a woman leader in my area [Oke Arin]. I joined politics because of my people.' According to her, her political activism had attracted the attention of the iyaloja of Lagos, who was keen to have iyalojas in every market coordinating political support for the party aligned with the traditional chiefs.

Based on the governance structure of the iyaloja-led market association, the male members of the team seemed to be the main implementation officers and enforcers of spatial controls. According to the secretary of the association (a man), there are seven main posts: iyaloja, babaloja, secretary, financial secretary, treasurer, chief of the task force and assistant iyaloja. However, there are sixteen 


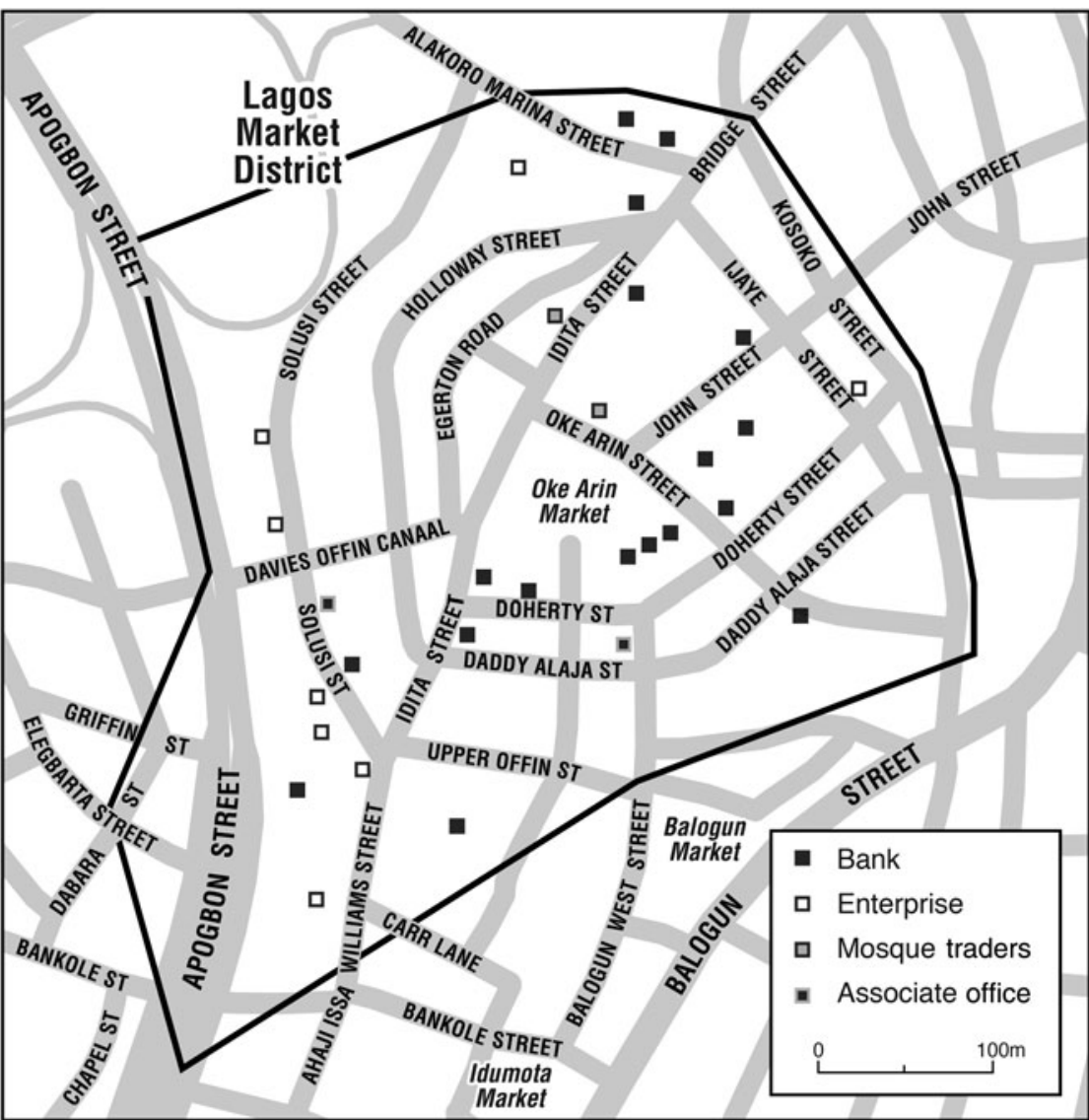

Map data (C) OpenStreetMap contributors, CC-BY-SA, opendatacommons.org

FIGURE 3 Area map of Oke Arin market showing the main streets.

executive members if one includes the members of the task force. All the members of the task force are men, which means that there are twelve men and four women in the executive of the association. The task force members enforce the rules of the market, in particular seizing the wares of traders who transgress their spatial boundaries. The secretary explained some of the infractions and penalties as follows:

We don't tolerate fights in our area, and if you do, there is a penalty charge of NGN 5,000 , and if you are asked not to go beyond a particular boundary, the goods will be seized if you do; that is why we have some goods in our custody and like you can see some traders coming to collect their goods - they have defaulted one way or the other and they are to pay NGN 2,000 for going beyond where we ask them to stay.

The day I interviewed the association members at their office, there were five allegedly errant women traders grovelling and begging to reclaim their goods, 
while the secretary scolded them and insisted that they pay up in order to retrieve their wares.

While many of the women traders surveyed (76 per cent) said that they do not belong to any association, the iyaloja-led market association says that they all do and forces compliance with market rules and imposes fees. In effect, belonging to the traditional (iyaloja-led) market association is compulsory. Setting up shop in a particular area ties a trader to the jurisdiction of the iyaloja in charge of that part of the market. The association's secretary explained it thus:

We have what we call automatic membership. We have a territory and we control a particular area. Once you rent a shop within our vicinity, you have automatically become a member and we will come to you and tell you our system and that is how it works. But for some other associations, it is voluntary.

There are rarely meetings or consultations with the traders; rather, the market association executives pass information on fees, dues and changes (such as roadworks in the market) and traders are expected to comply. Compliance and control are achieved through threats and the application of violence - often by seizing traders' wares and making them pay double what was originally demanded before they can redeem the goods. This relates to Massey's (1994: 180) point that spatial control can be enforced 'through the power of convention or symbolism, or through the straightforward threat of violence'.

Despite the iyaloja's political role, it is important to note that those who collect the taxes and dues and run other key aspects of the market administration are men. Additionally, the main beneficiaries of her market politics are the politicians who run the traditional political machinery that appointed her in the first place. Indeed, as she said to me, she is rarely at the market as she has to shuttle between political meetings and associated social events called by the iyaloja general and her other iyaloja colleagues or government officials. It took several months for me to hold a meeting with her in the market due to her other engagements. In her absence, the governance and control of the market are firmly in the hands of the men in her executive, particularly the secretary. Although the secretary lists the 'protection' of the traders as the main role of the association, many women traders feel otherwise about the relationship. Based on the comments of many women traders, they experience the market association as oppressive and marked by extortion. Most women traders would rather not discuss the association for fear of being overheard, and many said that it was best to pay the market dues promptly and avoid any issues with market officials.

Igbo traders have had seemingly unavoidable run-ins with the iyaloja-led market association. Organized as the Oke Arin Traders Association, the association's executives state that their goal is to protect the interests of their members (mostly Igbo male traders) in the market. Unlike other sector-based associations, such as the Aluminium Association, the Oke Arin Traders Association is registered with the Corporate Affairs Commission, maintains an office, and claims to have political clout that is not dependent on the iyaloja-led association. This situation seems to support Peil's (1991: 38) suggestion, based on her study of Lagos, that 'a competitive and manipulative outlook has often made Igbo migrants less acceptable to their hosts than more passive newcomers. They have shown a strong inclination to group together to further their mutual interests.' 
In addition to their economic interests, the Igbo traders claim to have become a political force to be reckoned with in the local politics of the Oke Arin area. But, from my observation, the Oke Arin Traders Association does not have much recognition beyond Igbo traders. In many ways, the association seems to be the Igbo traders' response to feelings of marginalization and oppression by a market governance system that treats them as 'outsiders'.

Significantly, the Oke Arin Traders Association attracted the attention of the market authorities and local politicians when it succeeded in causing a partial closure of the market for a full day, ostensibly to hold a meeting but in reality to flex its powers and to achieve better recognition. The president noted that the iyaloja had summoned him after the incident, angered by the Igbo traders' audacity in closing 'her' market. After the reconciliatory meetings, the peace deal included an agreement that the Igbo traders' association would collect market dues from its members and send a proportion to the iyaloja for onward transmission to the government and its agencies. The Igbo traders' association considers the new arrangement a huge political and economic success. Not only did they gain the right to collect (and appropriate) some of the dues and levies, the agreement provided insulation from harassment by agents of the iyaloja-led association.

Interestingly, all thirty officials of the Igbo Oke Arin Traders Association - ten executive members and twenty sectional chairmen and secretaries - are men. The president said that the association has about 2,000 registered members, and, of these, forty are women - mostly Igbo but also a few Yoruba women who trade in wines and imported foods. However, the president acknowledged that many traders, mostly Yoruba women, do not belong to the Igbo-led association. According to the president, the Yoruba see themselves as the owners of the market and prefer to deal with the iyaloja.

Despite this, the Igbo Oke Arin Traders Association is eager to maintain and further the gains it has made so far in carving out a space for (self-)governance in Oke Arin. To that end, the association arranged in June 2015 to pay a courtesy call on the 'iyaloja general of Nigeria' (the daughter of Bola Tinubu, the leader of the ruling party) at Alausa (the seat of state government). My attention was drawn to the visit when I noticed a new photograph hanging on the wall of the association's office. It was a happy group photograph of the association's key executive with the 'iyaloja general of Nigeria'. Surprisingly, the association had carefully included three women members in its delegation. The photograph showed four of the association's executive members, the three women (with Igbo-sounding names) and the iyaloja general. The executive members had convinced the three women to go along to the meeting because they realized that it would not look good meeting the iyaloja general of Nigeria with no women among them. This suggests that, beyond the ethnic card, the Igbo traders were playing the gender card to secure their space practically and symbolically in the market.

Despite their recent gains, there are numerous sources of discontent for the executives of the Igbo traders. The iyaloja-led association and the local government do not consult or even inform them about major decisions that affect the market. For instance, when the iyaloja general of Lagos Island died in July 2015 and all markets on the island, including Oke Arin, were ordered to close in order to mourn her, the Igbo association president had no advance information. Similarly, he and his team were not informed about the roadworks on Sanusi-Olusi 
Street in January 2016. Perhaps as a reaction to their perceived mistreatment, but also as a result of their own attitudes, the Igbo male traders often spoke disparagingly about the Yoruba women traders - and, indeed, about all women. They generally modified their behaviour, and some even spoke the Yoruba language, in order to get on better in the market, but these ingrained attitudes often seeped out and did not help their relationships with Yoruba women.

Yoruba women's relationships with Hausa/Fulani (almost always men) were more straightforward and relatively easy to navigate for at least two reasons. First, most of the Hausa/Fulani in Oke Arin are fruit hawkers and head porters and so are socio-economically subordinate. Second, compared with the Yoruba and Igbo, there is a negligible number of Hausa/Fulani in the market and they are not organized around their ethnic identity. Additionally, they present a more docile and peaceable image than the Igbo. Although that image seemed to have been somewhat dented by the terrorist group Boko Haram, the aboki or mallam (as they are generally called) remained trustworthy and helpful, and Oke Arin traders, including Yoruba women traders, typically hired them for a few hours to assist in setting out wares or to transport goods from warehouse to shops.

In sum, the spatial practices of market governance at Oke Arin are perceived as exploitative by most Yoruba women traders and compliance is achieved through threats and the actual use of force. Based on ethnicity, the Yoruba women traders enjoy a symbolic dominance over members of other ethnic groups (including Igbo male traders) as they are the 'owners' of the land. However, that construct of ethnic dominance over the Igbo is constantly in danger of collapse and seems to be maintained mostly through cautious and minimal engagement with the Igbo.

\section{Ownership and access to shops, stalls and open spaces}

The data from Oke Arin show that 91 per cent of women traders are not able to own their trading spaces (even if they have the money to do so) because the owners insist on rental only. This reinforces the prevalent gender construction of men as property owners and women as able to operate in the space only with men's permission. The case of Mrs Musa, ${ }^{1}$ aged forty-two, a trader in toothpastes and soaps, provides an example of this gendered struggle for control of the trading space. She rented her shop four years ago and each year her landlord increased her rent. In 2016, the landlord doubled the rent from NGN 200,000 to NGN 400,000 (about US\$550 to US\$1,100). She pleaded with him that her business was barely surviving and she could not afford any increase. He asked her to move out if she could not pay. Mrs Musa's appeal to the office of the iyaloja to help her plead with the landlord yielded no results. As she could not afford to pay, she left the market altogether.

Like Mrs Musa, many of the women traders have been subject to eviction based on all sorts of reasons, ranging from landlords wanting to renovate the property to needing the space for their own use. Of the thirty-five women interviewed in depth,

\footnotetext{
${ }^{1}$ The names of all the women traders have been changed to preserve their anonymity.
} 
fifteen of them had had to relocate and/or renegotiate their trading spaces in Oke Arin in response to such eviction notices. In many cases, eviction notices were used as a precursor to rent increases. One trader who was going through the displacement of an eviction during my field research was Mrs Opeyemi, aged fifty, a dealer in children's second-hand clothing. She had been at her location in Oke Arin for ten years and had endured five increases in her rent during that period. But in December 2014, her landlord told her she would have to leave entirely as he was working with private developers to remodel the building. Although the landlord promised to give her and his other former tenants first refusal on the new premises, she feared that the rent may be too steep, especially since the landlord had said he could not yet give them any idea of what the rent might be until the remodelling was complete.

The relations of power mediated by space ownership in the market only occasionally find women in a privileged position. A scene that played out on one of the days I was at the Igbo Oke Arin Traders Association office in Offin Canal Street spoke volumes about the power that comes with space ownership. A middle-aged woman barged into the office and complained loudly about the misuse of the toilet in the building. She threatened to throw out any tenants who persisted in letting outsiders use the toilet. The association president pleaded with and placated her, explaining that he had visitors and had to allow them to use the toilet. He suggested that it would be better for the tenants to hire a cleaner who they could pay by making contributions rather than the landlady's wards doing the cleaning. The president immediately made an initial contribution of NGN 3,000 (about US\$9). The woman's anger was assuaged and she left. I learned that she had recently inherited the building as her share of family property and was therefore the landlady. The president noted that, due to lack of space, everyone has to tread carefully with their landlords (and, in his case, landlady).

Mainly due to the costs but also because of the paucity of shops in perceived viable locations, many traders rent the open spaces in the market streets or resort to hawking. Unable to secure shop spaces, they operate in the margins, actively pushing and renegotiating the boundaries of legality and illegality. Some of those who have shops also occasionally send their assistants onto the streets, where they perceive there are more customers. Kemi, aged forty-two, who sells Ankara fabrics and has had a shop in Oke Arin for fifteen years, said that she occasionally sends her twenty-year-old female assistant to the main road, John Street, when business is slow. She argues that some shoppers who are time-pressed often do their shopping along the roads. So, with this strategy, she is able to maximize the opportunity to make sales from both types of space - her shop and the street. This compares with Kwami's point in relation to the Ghanaian market context that 'the margins constitute a multiplicity and continuum of spaces that is not static, with people situated in multiple intersections of the margins in different contexts, sometimes oscillating between centers and margins' (Kwami 2016: 151).

Operating in the open spaces implies a more precarious and constant renegotiation of trading spaces. Despite paying fees and bribes to market officials, those who trade in the open spaces get no protection if and when opposing or superior authorities come after them. In Oke Arin, such authorities frequently do so. Similar to Kinyanjui's (2013) finding with respect to Nairobi, traders on 
the main roads around Oke Arin market face periodic raids by Lagos Island local government agents in charge of the central business district. A majority of traders on these main roads around Oke Arin are young (Igbo) men, dealing in secondhand clothing and household items. Yoruba women traders on the roads tend to have reached an agreement with certain government agents and nearby shop owners, so they rarely have their goods seized, unlike the Igbo male hawkers.

Apart from raids, the government engages in spatial politics in the market in at least two other ways: one, by ostensibly rebuilding and remodelling roads and spaces; and two, by charging taxes for space and signage. In January 2016, based on its agreement with Lagos Island local government, the state government embarked on the rehabilitation of Sanusi-Olusi Street, a main artery within Oke Arin. While the roadworks were one of the improvements the market leaders had been requesting, the beginning of the work took the market leaders and traders by surprise. The iyaloja-led association was informed just three days prior to the start of the roadworks, while the Igbo Oke Arin Traders Association was not informed at all. Apparently, the power relations between government officials and market leaders dictate that sharing such plans with market leaders is at the government's discretion. Spatial politics also construct land, roads and streets as being 'owned' by the government. Thus, government officials are at liberty to decide on and to recreate public spaces and rights of way without recourse to public debate or consultation.

In the political pecking order, the market leaders are above the traders. Having received information on the roadworks just a few days earlier, the iyaloja-led association in turn informed the traders a couple of days in advance (which happened to be a weekend). Understandably, the shock and displacement were worse for the traders, as most got only a day's notice. Even those with legal shop locations were not protected from the loss of space. The new and wider drainage planned involved the demolition of numerous shops and the closing of the stalls in the open space in the area. None of the affected traders were offered any compensation or mitigation for the loss of space or the negative impact on their trading.

Eight of my research respondents on Sanusi-Olusi Street were affected to varying degrees by the roadworks. Two of the most affected were Alhaja Oshodi, aged sixty-three, a trader in tomato paste, spaghetti and sugar, and Madam Juliana, aged sixty, a dealer in detergents, candles and insecticides. The front parts of their shops were dug up to become part of the planned drainage system. Alhaja Oshodi was distraught. She told me that she heard about the plans only the weekend before the work started on Monday. She had no time to make alternative plans. For Madam Juliana, she still had about a third of her shop left, from which she was operating. She had placed a plank across the construction ditch to provide access to what remained of her shop.

For the traders who operate in the open spaces, their extreme vulnerability in the spatial politics of the market was further illustrated by the situation arising from the Sanusi-Olusi roadworks. Some of them had paid a full year's advance rent for 2016 (collected in December 2015) to agents of the market leaders. The agents insisted that the payments were non-refundable and that the time the women could trade in the space would not be extended. I confirmed with one of the market leaders, who justified it by saying that everybody was suffering in one way or another from the inconvenience of the dislocation caused by the roadworks. Three of my respondents who fell into this category were Mrs Olatunji, 
aged forty-nine, who sells wines and seasoning; Iya Bunmi, forty-six, a trader in cleaning agents and antiseptics; and Adidat, thirty-four, who trades in beverages. Mrs Olatunji said that she had paid NGN 36,000 to the agents of the market officials in December as the next year's (2016) advance rent for her open space. The three women said that they had only their storage spaces inside some of the buildings within the market and they could have no displays there. Their trading strategy thus involved hanging around their former spaces and looking out for customers. When a deal was agreed, they then went to their storage space to pack up the goods. But Mrs Olatunji said that only very loyal customers had the patience for this process.

Secondly, taxes levied on traders for space reveal governmental spatial politics. A local government official confirmed that the traders in Oke Arin 'pay for different levies irrespective of what they are selling'. The taxes and levies are collected by the market association officials and remitted to the local government. Explaining this process, the official of the iyaloja-led market association noted that there was often an annual bargaining process between the association and the local government officials to arrive at the amounts to be charged each year. He said:

The local government has its own set of bills. At the end of every year, they will come with their proposal per shop; they might come with a bill of NGN 10,000, even more than that for the trade and lockup. They will now call the heads, the executives and delegates to hold a meeting with them and at the end of our discussion, we might now conclude to pay NGN 6,500 as annual trade and lockup for each shop per year; we will now ask for the local government bank account and do it collectively, pay into the bank.

Essentially, the market association officials are the link between the government and the traders. The government needs the market associations to be able to collect the taxes and levies because it does not have the resources to do so itself. In this way, market associations have ample power to subordinate the traders and to twist the arm of the government and its agencies into looking the other way even when they are aware of embezzlement. According to the hierarchy of Oke Arin spatial politics, the state government is placed highest, followed by the local government, then the market association officials, and lastly the traders. This hierarchy is also gendered, with a greater number of men at the top of the totem pole.

\section{Market facilities and amenities}

Gendered spatial relations and control in Oke Arin are most evident in the use of market facilities such as waste management, toilets and drainage. The key actors in the market - traders, market association leaders and government agencies - all come into play in this arena.

In relation to waste management, the Lagos Waste Management Authority (LAWMA) was set up 'to be responsible for the collection and disposal of municipal and industrial waste, as well as for the provision of commercial waste services to the State and Local Governments'. ${ }^{2}$ LAWMA is in charge of solid waste

\footnotetext{
${ }^{2}$ See the LAWMA website at <http://www.lawma.gov.ng/>.
} 
collection in markets, including Oke Arin. Explaining the system they have set up for cleaning Oke Arin market, LAWMA officials interviewed noted:

\begin{abstract}
We arranged sweepers that clean the market after close of business, I mean at night. These sweepers do the job and pack the dirt at our designated place. Because most of the traders can't do the cleaning before they close for the day, so we advised them to do this [hire sweepers] and they agreed. The service is very effective and our trucks pack the dirt at night, when the traders have closed because the road is very narrow and the truck cannot move into the market during the daytime. But we have our waste bin in some areas, like under the bridge of Apogbon, Idumota, Oluwole Park. In all these areas, the sweepers do the cleaning every day. On Thursdays, which is the environmental day for all the traders in Lagos State markets, the trucks move round the markets before the commercial activities commence.
\end{abstract}

The LAWMA account differs slightly from what the Oke Arin women traders reported. Many of them said that, despite the LAWMA dues collected by the market associations, they have to pay sweepers for the daily cleaning of their sections. They are also required to report early to their shops on Thursdays for the weekly environmental sanitation; failure to do so results in the iyaloja-led association locking up their shops and fining them NGN 2,000 (about US\$6) before reopening. On their part, LAWMA officials allege that the traders do not do their bit. According to LAWMA:

The traders find it difficult to do simple things. Since these traders all have sales girls, they can just be instructing them to clean their environment and pack the garbage to where our bin is. It's a very simple thing but they are so carried away with their social life, they are not organized at all.

However, the executives of both the iyaloja-led association and the Igbo traders' association in Oke Arin allege that many of the sanitation infractions are caused by residents, not the traders. The president of the Igbo traders' association noted that 'even on Sundays [when] we don't open our shops, the whole environment is littered and so dirty, and by Monday morning you will see heaps of garbage and that is what we are facing in this market'.

With regard to payment for its services, LAWMA finds it most convenient to agree a standard bill for each section of the market with the iyaloja-led associations. The associations collect from traders and pass on the fees to LAWMA. LAWMA officials detailed the charges for each section of the market. It is simple to work out that, with NGN 500 charged to each trader per month, much more will be collected by the market associations than is required to pay the total bill for each section. When I pointed this out to LAWMA officials, it turned out that they already knew. Based on past experiences of unsuccessfully trying to carry out the collection itself, LAWMA recognizes that it 'cannot do anything without the association being involved'. As a basis for their continued symbiotic relationship, the market leaders had clearly told the LAWMA officials not to disclose how much they charge. The market associations help LAWMA collect fees from the traders and in turn use LAWMA's name to line their own pockets.

The Igbo Oke Arin Traders Association demanded the opportunity to run some sections of the market due to the inflated LAWMA charges and the non-payment of LAWMA fees that caused the entire market to be locked up in 2014. The 
compromise reached with the iyaloja-led association was for the Igbo traders' association to collect dues in the sections where Igbos predominate and then pass them on to the iyaloja's team for onward transmission to LAWMA. Ironically, the Igbo traders' association executive concedes that what it collects is more than what is remitted, explaining that what remains after remitting the LAWMA dues 'is used to run the office'. However, the exact figure for the difference between the amounts collected and remitted was a closely guarded secret. Thus, the spatial politics of environmental sanitation is rife with institutional collusion and corruption that short changes traders, particularly women who are on the lower rung of the power hierarchy.

The Oke Arin market traders' challenge to environmental sanitation does not end there. Due to its partly residential status, the market straddles two classifications in LAWMA's set-up. Residential areas are supposed to be the responsibility of private waste management support operators. LAWMA explained the unique challenge with Oke Arin thus:

The traders are to do the cleaning and pack the waste [in] the bin, but the residences are also causing more difficulties in this area. Although the private waste operators have been attached to these residences, the occupants dump their dirt on [the] street. Even those that are staying [in] a storey building will drop their dirt downstairs and litter the street with their garbage.

Even though LAWMA and the local council know this, the traders' shops are locked if there is garbage around them. On this issue, the Igbo traders' association disagreed with the government and its agencies and stood up for the traders. The president noted: 'As an association we have been to court on several occasions concerning this issue and the way it is going now. I still see that we will soon go to court again because those things [putting garbage on the streets] are not being done by the traders.'

Unlike solid waste management, which is partly privatized by the government, the management of toilets in Oke Arin has been fully privatized. Encouraged by the local council, private contractors build and maintain the toilets that serve the market. The toilet managers charge users NGN 30 to urinate and NGN 50 to defecate. The toilets, located in four different sections of the market, are basic closets with five or six tiny stalls with cement floors. Incidentally, many of the Yoruba women traders interviewed do not use the public toilets regularly. Many confided that they use their banks' toilets. With twenty-two bank branches around Oke Arin market, the women often bank with one close to their shop. When nature calls, as customers they can use the banks' better maintained toilets at no additional cost. So, the traders are able to claim additional space and benefits from their relationships with the banks.

\section{Conclusion}

In this article, I have used Massey's concept of gendered space to examine how women traders negotiate spatial relationships to facilitate their trading ventures. The findings agree with Massey's concept by showing that male dominance in the wider social relations of power in Lagos is reproduced in the market 
context. In other words, allusions to women being in charge in the market are more imagined than real. The social relations in the market are gendered (to men's benefit) and the market space is, as Massey (1994: 154) noted, 'full of power and with internal structures of domination and subordination'. These internal structures are evident in the governance of, ownership of and access to space in Oke Arin. However, the attempts of several structures to subordinate Yoruba women traders are contested, as the women employ various resistance strategies to claim and maintain space.

This article can be encapsulated in the following key findings. First, the structure of property ownership makes it difficult for most women traders (91 per cent) to own their trading spaces. This structure reinforces the domination of men as property owners and subordinates women, who are forced to operate in trading spaces only with men's permission. This has implications for women's sense of spatial control and how they run their businesses. It puts them in a vulnerable position where landlords can increase their rents arbitrarily or evict them and they have little recourse to justice.

Second, rather than protect women traders, the iyaloja-led market association is effectively an arm of the government and maintains its power and control over the women traders through threats and the use of violence. Membership is non-voluntary and dues are forcibly collected, including through the seizure of goods. Essentially, the women traders are forced into membership of an association in which they have neither a voice nor a vote.

Apart from imposing levies and taxes, government agencies collaborate and sometimes collude with market associations to subordinate and cheat women traders. The market associations collect overcharged dues and fees on behalf of the local government area and LAWMA, allowing market leaders to pocket the excess funds received from 'taxing' market women.

Lastly, Yoruba women traders adopt various strategies to enable them to overcome the strictures of relationships with dominant market and government institutions. These strategies range from compliance to entreaties and surreptitious rule breaking, pushing the boundaries of legality and possibility. As evidenced by their use of banks' toilets, they may also exploit their relationships in order to secure claims to additional spaces for their benefit.

\section{References}

Adebanwi, W. (2004) 'The city, hegemony and ethno-spatial politics: the press and the struggle for Lagos in colonial Nigeria', Nationalism and Ethnic Politics 9 (4): $25-51$.

Barnes, S. T. (1975) 'Voluntary associations in a metropolis: the case of Lagos, Nigeria', African Studies Review 18 (2): 75-87.

Barnes, S. T. (1986) Patrons and Power: creating a political community in metropolitan Lagos. Manchester: Manchester University Press.

Byfield, J. (2002) The Bluest Hands: a social and economic history of women indigo dyers in Western Nigeria, 1890-1940. London: Heinemann.

Clark, G. (1994) Onions Are My Husband: survival and accumulation by West African market women. London: University of Chicago Press. 
Eades, J. (1980) The Yoruba Today. Cambridge: Cambridge University Press.

Fourchard, L. and A. Olukoju (2007) 'State, local governments and the management of markets in Lagos and Ibadan since the 1950s' in L. Fourchard (ed.), Gouverner les villes d'Afrique: État, gouvernement local et acteurs privés. Paris: Karthala.

George, A. (2011) 'Within salvation: girl hawkers and the colonial state in development era Lagos', Journal of Social History 44 (3): 837-59.

Handwerker, W. P. (1974) 'Changing household organization in the origins of market places in Liberia', Economic Development and Cultural Change 22 (2): 229-48.

Ikioda, F. (2012) 'Limits to communities of practice in an open air market: the case of the Alaba-Suru market, Lagos, Nigeria'. PhD thesis, University of Sheffield.

Ikioda, F. (2014) 'Communities of practice in competitive settings: exploring the role of associations of market traders in marketplaces in Lagos, Nigeria', Knowledge Management for Development Journal 10 (2): 105-16.

Kinyanjui, M. (2013) 'Women informal garment traders in Taveta Road, Nairobi: from the margins to the center', African Studies Review 56 (3): 147-64.

Kwami, J. (2016) 'Development from the margins? Mobile technologies, transnational mobilities, and livelihood practices among Ghanaian women traders', Communication, Culture and Critique 9 (1): 148-68.

Lagos State Ministry of Information (1988) Lagos State Handbook. Ikeja: Lagos State Printing Corporation.

Lawal, A. A. (2004) 'Markets and street trading in Lagos' in T. Falola and S. J. Salm (eds), Nigerian Cities. Trenton NJ: African World Press.

Little, K. (1972) 'Voluntary associations and social mobility among West African women', Canadian Journal of African Studies 6 (2): 275-88.

Mann, K. (1983) 'The dangers of dependence: Christian marriage among elite women in Lagos colony, 1880-1915', Journal of African History 24 (1): 37-56.

Massey, D. (1994) Space, Place and Gender. Minneapolis MN: University of Minnesota Press.

Mba, N. (1982) Nigerian Women Mobilized: women's political activity in southern Nigeria, 1900-1965. Berkeley CA: Institute of International Studies, University of California.

Mba, N. (1987) 'Women in Lagos political history' in A. Adefuye et al. (eds), History of the Peoples of Lagos State. Lagos: Lantern Books.

Meagher, K. (2007) 'Introduction: special issue on "informal institutions and development in Africa", Africa Spectrum 42 (3): 405-18.

Meagher, K. (2011) 'Informal economies and urban governance in Nigeria: popular empowerment or political exclusion?', African Studies Review 54 (2): 47-72.

Peil, M. (1991) Lagos: the city is the people. London: Belhaven Press.

Prag, E. (2013) 'Mama Benz in trouble: networks, the state, and fashion wars in the Beninese textile market', African Studies Review 56 (3): 101-21.

Rao, N. et al. (2009a) Gender and Growth Assessment - Nigeria: national overview. Department for International Development (DFID) and Canadian International Development Agency (CIDA) paper. Norwich and Ibadan: International Development, University of East Anglia and Nigerian Institute of Social and Economic Research <https://www.uea.ac.uk/devresearch/research-themes/ gender/gender-and-growth-assessment-nigeria>, accessed 15 October 2012.

Rao, N. et al. (2009b) Gender and Growth Assessment - Nigeria: Bauchi, Cross River, Kano and Lagos State Reports. DFID and CIDA paper. Norwich and 
Ibadan: International Development, University of East Anglia and Nigerian Institute of Social and Economic Research < https://www.uea.ac.uk/devresearch/research-themes/gender/gender-and-growth-assessment-nigeria $>$, accessed 15 October 2012.

Scott, J. (1985) Weapons of the Weak: everyday forms of peasant resistance. New Haven CT: Yale University Press.

Silvey, R. (2006) 'Geographies of gender and migration: spatializing social difference', International Migration Review 40 (1): 64-81.

Sudarkasa, N. (1973) Where Women Work: a study of Yoruba women in the marketplace and in the home. Anthropological Papers 53. Ann Arbor MI: University of Michigan.

\begin{abstract}
Markets in Lagos, as in other parts of Yorubaland, are discursively constructed as spaces where women are in charge, perhaps based on their numbers. However, this article on the spatial relationships between women traders, the state and market institutions at Oke Arin in Lagos points to women's subordination and reflects Doreen Massey's concept of gendered spaces. Massey explains that spaces are in themselves gendered and that they also reflect and affect how gender is constructed and enforced in a specific context. The study is based on a sample of eighty Lagos (Yoruba) women traders and uses a combination of surveys, indepth interviews, observation and secondary data to examine gendered strategies for survival and accumulation. I argue that, contrary to the perceptions of powerful Lagos market women, Massey's 'internal structures of domination and subordination' are evident in spatial governance, ownership and access at Oke Arin. Therefore, in response to spatial politics and the dominating structures of market and government authorities, women traders devise strategies of resistance, sometimes pushing the boundaries of legality to secure their livelihoods.
\end{abstract}

\title{
Résumé
}

À Lagos comme dans d'autres parties du Yorubaland, les marchés se construisent discursivement comme des espaces où les femmes sont aux commandes, peut-être en raison de leur nombre. Cependant, cet article sur les relations spatiales entre les marchandes, l'État et les institutions du marché d'Oke Arin à Lagos suggère une subordination des femmes et renvoie au concept d'espaces genrés de Doreen Massey. Massey explique que les espaces sont en eux-mêmes genrés et aussi qu'ils reflètent et affectent la manière dont le genre se construit et s'applique dans un contexte spécifique. Basée sur un échantillon de quatre-vingt marchandes (yoruba) de Lagos, l'étude examine les stratégies genrées de survie et d'accumulation à travers des enquêtes, des entretiens approfondis, des observations et des données secondaires. L'auteur soutient que, contrairement aux perceptions de femmes fortes sur le marché de Lagos, les « structures internes de domination et de subordination » de Massey sont manifestes dans la gouvernance, la propriété et l'accès à l'espace à Oke Arin. En réponse à la politique spatiale et aux structures dominantes des autorités du marché et de l'État, les marchandes élaborent des stratégies de résistance, parfois en repoussant les limites de la légalité pour protéger leurs moyens de subsistance. 